\title{
PENGGUNAAN MEDIA PERMAINAN KARTU KWARTET PINTAR SEJARAH (KKPS) \\ DALAM UPAYA PENINGKATAN AKTIVITAS DAN HASIL BELAJAR \\ PADA SISWA KELAS X IPA 7 SMA NEGERI 1 SURAKARTA \\ SEMESTER GASAL TAHUN PELAJARAN 2017/2018
}

\author{
S a s m i t a $\mathbf{a}^{1}$ \\ Guru SMA Negeri 1 Surakarta \\ Jalan Monginsidi No.40, Margoyudan, Banjarsari, Kota Surakarta, Jawa Tengah 57134
}

\begin{abstract}
ABSTRAK
Tujuan Penelitian ini adalah: 1) untuk meningkatkan keaktifan semua siswa dalam proses belajar mengajar di dalam kelas X IPA 7 SMA N 1 Surakarta; 2) untuk meningkatkan hasil belajar semua siswa sehingga akan membawa dampak pada indek prestasi sekolah; 3) untuk meningkatkan keaktifan dan hasil belajar semua siswa di SMA Negeri 1 Surakarta. Metode yang digunakan dalam penelitian adalah penelitian tindakan kelas menggunakan Kartu Kwartet Pintar Sejarah. Hasil analisis dari tindakan kelas menggunakan Kartu Kwartet Pintar Sejarah adalah aktifitas belajar siswa dan hasil belajar siswa selalu meningkat pada tiap siklus. Implikasi dari penelitian ini adalah bahwa: 1) strategi pembelajaran merupakan hal yang sangat penting dilakukan guru dalam menyampaikan materi kepada siswa. Strategi pembelajaran menggunakan Kartu Kwartet Pintar Sejarah yang sudah dilakukan menunjukkan hasil adanya peningkatan pada aktifitas belajar dan hasil belajar siswa; 2) Hasil penelitian ini juga berimplikasi pada perubahan paradigma pembelajaran berpusat pada guru menjadi berpusat pada siswa. melalui pembelajarn menggunakan Kartu Kwartet Pintar Sejarah terbukti bahwa siswa lebih aktif, baik dari aspek visual, lisan, mendengarkan, menulis, dan emosional. Selain penggunaan Kartu Kwartet Pintar Sejarah juga mampu meningkatkan hasil belajar siswa. Hal tersebut tampak pada meningkatnya rata-rata kelas dan jumlah siswa yang mencapai ketuntasan belajar.
\end{abstract}

\section{Kata Kunci: aktifitas, hasil belajar, kartu kwartet pintar sejarah}

\begin{abstract}
The purpose of this research are: 1) to improve the activity of all students in teaching and learning process in class X IPA 7 SMA N 1 Surakarta; 2) to improve the learning outcomes of all students so that it will have an impact on the school achievement index; 3) to improve the activity and learning outcomes of all students in SMA Negeri 1 Surakarta. The method used in this research is classroom action research using Smart History Quartet Card. The analysis of class actions using Smart Quartet Card History is the student's learning activity and student learning outcomes are always increasing in each cycle. The implication of this research is that 1) learning strategy is very important thing done by teacher in delivering material to student. Learning strategy using Smart Quartet Card History that has been done shows the result of the increase in learning activities and student learning outcomes; 2) The results of this study also have implications for the paradigm shift of learning centered on teachers to be studentcentered. through learners using Smart Quartet Card History proves that students are more active, both from the visual aspect, oral, listening, writing, and emotional. In addition to the use of Smart Quartet Card History is also able to improve student learning outcomes. This is evident in the increase in the average class and the number of students who achieve mastery learning.
\end{abstract}

Keywords: activity, learning outcomes, smart card quartet history

\footnotetext{
${ }^{1}$ Penulis Koresponden

E-mail address: sazmhi@gmail.com doi: http://dx.doi.org/10.25157/ja.v4i2.905
} 


\section{PENDAHULUAN}

Pembelajaran di kelas yang aktif, kreatif dan menyenangkan merupakan sebuah proses yang diharapkan oleh semua fihak baik itu guru, siswa dan orang tua karena proses pembelajaran yang berjalan efektif diharapkan akan mendapatkan hasil yang maksimal. Namun dalam kenyataannya proses tersebut sulit untuk di dapatkan apalagi dalam proses pembelajaran sejarah, seperti halnya keadaan siswa di kelas X IPA 7 SMA Negeri 1 Surakarta tahun pelajaran 2017-2018 pada keadaan awal sebelum penelitian dilakukan keaktifan siswa sangat rendah hal ini dapat peneliti lihat dari minat bertanya dari dua pertemuan hanya 6 orang yang mengajukan pertanyaan, 4 orang tidak membawa buku catatan dan 4 orang ngobrol sendiri ketika pelajaran berlangsung sementara ketika peneliti mengajukan pertanyaan hanya 4 orang yang merespon untuk mencoba menjawab. Begitu juga dengan hasil belajar yang didapat dari siswa kelas X IPA 7 SMA Negeri 1 Surakarta tahun pelajaran 2017-2018 semester 1 pada materi Kehidupan masyarakat pra aksara di Indonesia dari 33 siswa yang mendapatkan nilai diatas KKM hanya 21 siswa yang berarti hanya sekitar 60\% kurang.

Keaktifan siswa dan hasil belajar yang rendah mungkin di karenakan peneliti dalam mengajar belum menggunakan media permainan kartu kwartet pintar sejarah (kkps), selama ini peneliti menggunakan model pembelajaran dengan menggunakan metode ceramah peneliti menyampaikan materi dengan berceramah siswa mendengarkan dan meminta siswa untuk mencatat sesuatu yang mereka anggap penting peneliti berpendapat bahwa dengan model pembelajaran tersebut maka materi segera dapat terselesaikan namun satu sisi siswa hanya sebagai obyek, pembelajaran hanya berlangsung satu arah sehingga keaktifan siswa rendah dan hasil yang di peroleh juga kurang maksimal.

Harapan yang ingin peneliti capai setelah penelitian adalah meningkatnya keaktifan dan hasil belajar siswa karena hasil belajar yang rendah akan berdampak pada sulitnya siswa untuk naik kelas karena untuk dapat naik kelas siswa tidak di perkenankan memiliki nilai di bawah KKM lebih dari tiga mata pelajaran, lebih luas lagi rendahnya hasil belajar juga berdampak pada turunnya indek prestasi sekolah yang berdampak pada penilaian akreditasi sekolah dan penerimaan siswa di PTN melalui jalur undangan.

Kondisi akhir yang peneliti harapkan setelah peneliti menggunakan media permainan kartu kwartet pintar sejarah (KKPS) adalah keaktifan dan hasil belajar siswa meningkat, dengan banyak memberikan model game atau permainan siswa diharapkan dapat mengikuti pelajaran dengan senang, gembira dan ceria sehingga dapat mengembangkan kemampuan juga potensi yang ada di dalam dirinya secara maksimal,keikut sertaan siswa dalam proses belajar tidak ditatap sebelah mata tapi siswa juga di anggap sebagai subyek sehingga keaktifan siswa meningkat dan pada akhirnya hasil belajar pun meningkat. Hal ini sesuai dengan fungsi dan tujuan pendidikan nasional yang tertuang dalam UU No.20 Tahun 2003, yaitu bahwa pendidikan nasional berfungsi mengembangkan kemampuan dan membentuk watak serta peradaban bangsa yang bermartabat dalam rangka mencerdaskan kehidupan bangsa serta mengembangkan potensi peserta didik agar menjadi manusia yang beriman dan bertaqwa kepada Tuhan Yang Maha Esa, berakhlak mulia, sehat, berilmu, cakap, kreatif, mandiri dan menjadi warga negara yang demokratis serta bertanggung jawab. ${ }^{2}$

Pada kondisi awal siswa di kelas X IPA 7 SMA Negeri 1 Surakarta tahun pelajaran 20172018 semester 1 pada materi Kehidupan masyarakat pra aksara di Indonesia keaktifan dan hasil belajar sangat rendah harapan yang peneliti inginkan keaktifat dan hasil belajar dapat meningkat sehingga siswa tidak mengalami kesulitan ketika kenaikan kelas dan diharapkan dapat menunjang meningkatnya indek prestasi sekolah apabila hasil belajar yang diperoleh semua diatas KKM.

Peneliti dalam pembelajaran di kondisi awal menggunakan model pembelajaran ceramah dalam memberikan materi, pembelajaran yang hanya berlangsung satu arah menyebabkan keaktifan siswa rendah dan hasil belajar siswa pun juga rendah dengan penerapan media Kartu Kwartet Pintar Sejarah (KKPS) siswa di ajak bermain sehingga siswa dituntut untuk lebih aktif kreatif mencari solusi dalam masalah-masalah yang dihadapi sehingga diharapkan keaktifan dan hasil belajar meningkat.

\footnotetext{
${ }^{2}$ Mulyasa E., 2007. Standar Kompetensi dan Sertifikasi Guru, Bandung, Remaja Rosdakarya, hal. 4
} 
Dalam Kamus Besar Bahasa Indonesia permainan adalah hal bermain, perbuatan bermain. Perbuatan yang dilakukan dengan tidak sungguh-sungguh untuk meraih kesenangan tanpa mempertimbangkan hasil akhir. ${ }^{3}$ Dananjaya menyebutkan bahwa permainan adalah kegiatan menyenangkan dan suasana yang membebaskan, dapat menyuburkan kemampuan dan watak. ${ }^{4}$

Menurut Kamus Besar Bahasa Indonesia, kartu adalah kertas tebal berbentuk persegi panjang (untuk berbagai keperluan hampir sama dengan karcis). ${ }^{5}$ Sedangkan kuartet adalah kelompok, kumpulan, dan sebagainya yang terdiri atas empat. ${ }^{6}$ Dengan demikian dapat diambil pengertian bahwa kartu kuartet adalah sejenis permainan yang terdiri atas beberapa jumlah kartu bergambar, dan di dalam kartu tersebut tertera keterangan berupa tulisan yang menerangkan gambar tersebut. Biasanya tulisan judul gambar ditulis paling atas dari kartu dan tulisannya lebih diperbesar atau dipertebal dan tulisan gambar, ditulis dua atau empat baris secara vertikal di tengah-tengah antara judul dan gambar. Tulisan yang menerangkan gambar itu biasanya ditulis dengan tinta berwana.

Tulisan ini mencoba membahas mengenai pembelajaran sejarah menggunakan Kartu Kwartet Pintar Sejarah untuk meningkatkan aktifitas dan hasil belajar siswa. Aktifitas belajar menurut Sardiman (2001: 4) menuturkan bahwa belajar merupakan berbuat untuk mengubah tingkah laku, sehingga dapat dikatakan melakukan kegiatan. Aktivitas belajar adalah aktivitas yang bersifat fisik maupun mental. ${ }^{7}$ Berdasarkan pendapat tersebut dapat diambil pengertian bahwa belajar harus aktif atau melakukan suatu kegiatan, jadi tidak diam dan pasif

Hasil belajar menurut Nana Sudjana adalah perubahan tingkah laku siswa setelah melalui proses pembelajaran. Semua perubahan dari proses belajar merupakan suatu hasil belajar dan mengakibatkan manusia berubah dalam sikap dan tingkah lakunya. ${ }^{8}$

Melihat dari rendahnya keaktifan dan hasil belajar siswa maka peneliti perlu

\footnotetext{
3 Tim Penyusun Kamus Pusat dan Pengembangan Bahasa, 2008, Kamus Besar Bahasa Indonesia. Jakarta: PT. Gramedia Pustaka Umum, hal. 258

${ }^{4}$ Utomo Dananjaya, 2010, Media Pembelajaran Aktif. Bandung: Nuansa, hal. 35

${ }^{5}$ Tim Penyusun Kamus Pusat dan Pengembangan Bahasa, 2008, Kamus Besar Bahasa Indonesia..., hal. 628.

${ }^{6}$ Ibid. hal, 745.
}

melakukan tindakan dengan menerapkan media permainan kartu kwartet pintar sejarah (kkps). Tindakan pertama peneliti akan menggunakan media permainan kartu kwartet pintar sejarah (kkps) kelompok besar yaitu dengan membentuk kelompok bermain berjumlah 6 siswa dan untuk tindakan ke dua peneliti akan menerapkan media permainan kartu kwartet pintar sejarah (kkps) untuk kelompok kecil yaitu dengan membentuk kelompok bermain 2 siswa. Penerapan pembelajaran dengan media permainan kartu kwartet pintar sejarah (kkps) untuk meningkatkan keaktifan siswa dalam proses belajar mengajar dan untuk meningkatkan hasil belajar siswa.

Tujuan penelitian ini adalah bahwa melalui pembelajaran sejarah menggunakan Kartu Kwartet Pintar Sejarah untuk meningkatkan keaktifan siswa kelas X IPA 7 SMA Negeri 1 Surakarta tahun pelajaran 20172018, untuk meningkatkan hasil belajar siswa kelas X IPA 7 SMA Negeri 1 Surakarta tahun pelajaran 2017-2018, dan untuk meningkatkan keaktifan dan hasil belajar siswa kelas X IPA 7 SMA Negeri 1 Surakarta tahun pelajaran 20172018.

\section{METODE PENELITIAN}

Penelitian ini dilaksanakan di kelas X IPA 7 SMA N 1 Surakarta yang terletak di jalan Monginsidi No 40 Surakarta. Waktu penelitian pada semester gasal yaitu semester 1 tahun ajaran 2017/2018. Tempat penelitian ini sengaja dipilih karena siswa di kelas X IPA 7 SMA N 1 Surakarta.

Subyek penelitian menurut Suharsimi Arikunto subyek dalam penelitian adalah benda, keadaan atau orang tempat data melekat dan dipermasalahkan. ${ }^{9}$

Subyek dalam penelitian adalah siswa kelas X IPA 7 SMA Negeri 1 Surakarta semester gasal tahun pelajaran 2017-2018. Adapun obyek penelitian ini adalah aktivitas belajar dan hasil belajar siswa kelas X IPA 7 SMA Negeri 1

\footnotetext{
${ }^{7}$ Sardiman, A.M., 2004, Interaksi dan Motivasi Belajar Mengajar, Jakarta: Raja Grafindo Persada, hal 4.

8 Nana Sudjana, 2005, Penilaian Hasil Proses Belajar Mengaja. Bandung: Rasdakarya, hal, 3.

${ }^{9}$ Suharsimi Arikunto 2002. Prosedur Penelitian Suatu Pendekatan Praktik, Jakarta: Rineka Cipta, hal 66.
} 
Surakarta semester gasal tahun pelajaran $2017-$ 2018.

Bentuk data dalam penelitian ini dibagi dua yaitu data kuantitatif dan data kualitatif. Data kuantitatif merupakan data berupa angkaangka seperti nilai siswa setelah mengerjakan tugas berupa tes. Tes adalah serentetan pernyataan atau latihan serta alat lain yang digunakan untuk mengukur ketrampilan pengetahuan intelegensi, kemampuan atau bakat yang dimiliki individu atau kelompok. ${ }^{10}$

Data kualitatif didapatkan dari hasil pengamatan, seperti pada saat mengamati aktifitas siswa selama mengikuti proses pembelajaran sejarah materi Kerajaan HinduBudha. Dalam hal ini peneliti mencatat bentuk keaktifan siswa misalnya dalam mengajukan pertanyaan, menuangkan ide dan gagasan, melakukan presentasi dan lain sebagainya.

Data-data yang ada dalam penelitian ini diambil dari hasil pengamatan atau observasi selama penelitian dilakukan, yang meliputi kondisi awal yang terdiri dari data keaktifan siswa dan data hasil belajar siswa, siklus 1 yang terdiri dari data keaktifan siswa dan data hasil belajar siswa, dan siklus 2 yang terdiri dari data keaktifan siswa dan data hasil belajar siswa.

Sumber data dalam penelitian ini adalah sumber data primer atau subyek penelitian yang diperoleh secara langsung dari siswa kelas $\mathrm{X}$ IPA 7 SMA N 1 Surakarta semester 1 Tahun pelajaran 2017-2018.

Teknik yang digunakan dalam peneliti ini merupakan teknik pengumpulan data untuk memperoleh data aktifitas belajar siswa dan hasil belajar siswa kelas X IPA SMA N 1 Surakarta.
Teknik pengumpulan data berupa tes dan non tes.

Analisis data dalam penelitian ini didasarkan pada aktifitas dan hasil belajar siswa yang berupa angka-angka. Dengan demikian dapat dikatakan data yang dianalisis berupa data kuantitatif. Aktifitas belajar siswa akan diukur atau dihitung berdasarkan tingkat keaktifan belajar dan hasil belajar siswa kelas X IPA 7 SMA N 1 Surakarta mulai dari kondisi awal, siklus 1, dan siklus 2. Keaktifan siswa yang akan dihitung atau diukur terdiri dari 5 aspek, yaitu aktifitas visual, aktifitas lisan, aktifitas mendengarkan, aktifitas menulis, dan aktifitas emosional. Sedangkan hasil belajar dapat dilihat dari hasil tes yang dikerjakan oleh siswa, yang dapat dilihat dari lembar penilaian.

\section{HASIL PENELITIAN DAN PEMBAHASAN}

Sebelum melakukan tindakan, peneliti melakukan pengamatan mengenai aktifitas dan hasil belajar siswa pada mata pelajaran sejarah. Dari hasil pengamatan yang telah dilakukan, dapat dilihat bahwa 37, 87\% dari jumlah siswa telah melakukan aktivitas visual, 18, 93\% dari jumlah siswa telah melakukan aktivitas lisan, 63, $63 \%$ dari jumlah siswa telah melakukan aktivitas mendengarkan, 63, 63\% dari jumlah siswa telah melakukan aktivitas menulis, dan $25,75 \%$ dari jumlah siswa telah melakukan aktivitas emosional. Berikut ini tabel tentang persentase setiap aspek aktivitas siswa pada kegiatan pembelajaran yang telah dilakukan.

Tabel 2.

Keaktifan siswa Pra Siklus

\begin{tabular}{llll}
\hline No & Aktifitas yang diamati & Prosentase & Kategori \\
\hline 1 & Aktifitas Visual & $37.87 \%$ & Kurang \\
2 & Aktifitas Lisan & $18.93 \%$ & Kurang sekali \\
3 & Aktifitas Mendengarkan & $63.63 \%$ & Baik \\
4 & Aktifitas Menulis & $63.63 \%$ & Baik \\
5 & Aktifitas Emosional & $25.75 \%$ & Kurang \\
\hline
\end{tabular}

Hasil belajar Sejarah materi Kerajaan Hindi-Budha siswa di Kelas X IPA 7 SMA N 1 Surakarta pada kondisi sebelum dilakukan tindakan atau kondisi pra siklus adalah nilai terendah 50, dan nilai paling tinggi adalah 100 . Adapun rata-rata yang dicapai adalah 74,84 . Secara lebih jelas dapat dilihat dari tabel di bawah ini.

\footnotetext{
${ }^{10}$ Suharsimi Arikunto, ibid. hal, 127.
} 
Tabel 3.

Nilai tertinggi dan terendah Siswa Pra Siklus

\begin{tabular}{cc}
\hline Uraian & Nilai \\
\hline Nilai Terendah & 50 \\
Nilai Tertinggi & 100 \\
Nilai Rerata & 74,84 \\
Rentang Nilai & 50 \\
\hline
\end{tabular}

Salah satu indikator keberhasilan pelaksanaan pembelajaran menggunakan Kartu Kwartet Pintar Sejarah adalah apabila jumlah siswa yang dapat mencapai nilai standar KKM yaitu 75 ada sebanyak $80 \%$. Berikut tabel hasil belajar siswa.

Tabel 4

Data Hasil Belajar Siswa

\begin{tabular}{ccc}
\hline Nilai & Frekuensi & Presentase \\
\hline$\leq 75$ & 13 & 39.40 \\
$>75$ & 20 & 60.60 \\
Jumlah & 33 & 100 \\
\hline
\end{tabular}

Perlu diketahui bahwa aturan main bermain kartu kwartet pintar sejarah yang digunakan dalam pembelajaran dengan materi Kerajaan Hindu Budha, yaitu salah seorang siswa bertugas mengocok kartu kemudian membagikan kepada setiap regu bermain. Setiap regu mendapatkan 4 kartu dan sisa kartu ditaruh di tengah. Setelah semua regu mendapatkan kartu, permainan bisa dimulai. Dalam hal ini salah satu regu akan menyebutkan atau membaca nama atau judul kartu. Bagi regu lain yang memiliki kartu yang dimaksud akan menaruh kartu itu di bawah yang kemudian diambil oleh regu yang tadi mendapatkan kesempatan menyebut atau membaca judul kartu. Hal ini dilakukan secara bergantian hingga permainan selesai. Adapun permainan dianggap selesai setelah kartu habis dan pemenang didasarkan pada banyaknya kartu game yang diperoleh.

Pada tindakan siklus I ini, guru membagi siswa menjadi 2 kelompok, dimana masing-masing kelompok terdiri dari 16 siswa. Kartu kwartet pintar sejarah dimainkan oleh 4 regu bermain, di mana setiap satu regu terdiri dari 4 siswa. Dengan demikian guru hanya mengeluarkan atau membutuhkan 2 set kartu kwartet untuk bermain siswa. Setelah kelompok terbagi, guru membagikan 2 set kartu kwartet tersebut kepada masing-masing kelompok agar permainan segera bisa dimulai. Setelah semua siswa sudah siap maka permainan dimulai. Selama permainan dimulai guru mengawasi kegiatan yang dilakukan oleh siswa tersebut. Setelah permainan selesai, guru memberi kesempatan kepada setiap regu bermain untuk melakukan diskusi.

\section{Aktifitas Siswa}

Berdasarkan observasi yang dilakukan pada siklus I, terlihat bahwa 72, 72\% dari jumlah siswa telah melakukan aktivitas visual masuk dalam kategori baik, 46, 96\% dari jumlah siswa telah melakukan aktivitas lisan masuk dalm kategori cukup, 93, 93\% dari jumlah siswa telah melakukan aktivitas mendengarkan masuk dalm kategori baik sekali, 96, 96\% dari jumlah siswa telah melakukan aktivitas menulis masuk dalam kategori baik sekali, 53, 02\% dari jumlah siswa telah melakukan aktivitas emosional masuk dalam kategori cukup. Aktifitas siswa yang tergolong masih rendah yaitu terletak pada aktivitas lisan dan emosional. Pada aktivitas lisan, hasil diskusi hanya dipresentasikan oleh perwakilan kelompok sehingga anggota kelompok yang lain kurang berperan aktif dalam kegiatan presentasi. Siswa juga masih terlihat malu-malu dalam menyampaikan pertanyaan, ide, dan gagasannya. Secara lebih jelas gambaran mengenai atkifitas belajar siswa pada Siklus I dapat dilihat dari tabel dan diagram batang di bawah ini. 
Tabel 5.

Keaktifan siswa Siklus I

\begin{tabular}{clcc}
\hline No & Aktifitas yang diamati & Prosentase & Kategori \\
\hline 1 & Aktifitas Visual & $72.72 \%$ & Baik \\
2 & Aktifitas Lisan & $46.96 \%$ & Cukup \\
3 & Aktifitas Mendengarkan & $93.93 \%$ & Baik Sekali \\
4 & Aktifitas Menulis & $96.96 \%$ & Baik Sekali \\
5 & Aktifitas Emosional & $53.02 \%$ & Cukup \\
\hline
\end{tabular}

\section{Hasil Belajar Siswa}

Nilai ketuntasan pada mata pelajaran sejarah adalah 75. Jumlah siswa kleas X IPA 7 SMA N 1 Surakarta sebanyak 33 siswa. Diketahui bahwa nilai ketuntasan siswa sebelum dilakukan tindakan ada sebanyak 13 siswa atau sebesar 39.39\% yang tidak tuntas, dan 20 siswa atau sebesar 60, 60\% dinyatakan tuntas dalam pembelajaran sejarah materi Kerajaan Hindu-Budha. Pada Siklus I didapatkan hasil bahwa nilai terendah siswa adalah 60, sedangkan untuk nilai tertinggi 100. Adapun rata-rata yang diperoleh adalah 81,66 . Secara lebih jelas dpat dilihat dari tabel di bawah ini.

Tabel. 6

Perbandingan nilai siswa pra siklus dengan siklus I

\begin{tabular}{lcc}
\hline \multicolumn{1}{c}{ Uraian } & Kondisi Awal & Siklus I \\
\hline Nilai Terendah & 50 & 60 \\
Nilai Tertinggi & 100 & 100 \\
Nilai Rerata & 74,84 & 81,66 \\
Rentang Nilai & 50 & 40 \\
\hline
\end{tabular}

Siswa yang mencapai ketuntasan belajar, yaitu yang mencapai nilai 75 atau lebih pada mata pelajaran Sejarah materi Kerajaan Hindu-Budha sebanyak 28 siswa atau 84, 84\%, sedangkan yang tidak mencapai ketuntasan belajar sebanyak 5 siswa atau 15, 15\%. Dengan demikian dapat disimpulkan bahwa hasil belajar siswa dalam pembelajaran Sejarah materi Kerajaan Hindu Budha menggunakan Kartu Kwartet Pintar Sejarah pada Siklus I telah mengalami peningkatan, yaitu dari 20 siswa atau $60.60 \%$ menjadi 28 siswa atau $84,84 \%$. Secara lebih jelas dapat dilihat dari tabel dan diagram batang di bawah ini.

Tabel. 7

Perbandingan Hasil Belajar Siswa pra siklus dengan siklus I

\begin{tabular}{ccccc}
\hline \multirow{2}{*}{ Uraian } & \multicolumn{2}{c}{ Kondisi awal } & \multicolumn{2}{c}{ Siklus I } \\
& Frekuensi & Presentase & Frekuensi & Presentase \\
\hline$\leq 75$ & 13 & 39.40 & 5 & 15.15 \\
$>75$ & 20 & 60.60 & 28 & 84.84 \\
Jumlah & 33 & 100 & 33 & 100 \\
\hline
\end{tabular}

Berdasarkan hasil observasi dan refleksi yang telah diperoleh, aktivitas siswa yang muncul dirasakan kurang maksimal meskipun tetap terjadi peningkatan. Oleh karena itu, perlu adanya rencana perbaikan yang akan dilaksanakan pada siklus selanjutnya, yaitu siklus II. Adapun yang akan dilaksanakan pada rencana perbaikan yang akan dilaksanakan pada siklus II adalah dengan membuat 4 kelompok. Dengan demikian setiap regu bermain terdiri dari 2 siswa, yang sebelumnya 4 siswa. Hal ini bertujuan agar siswa lebih banyak menguasai materi serta lebih mudah dalam membagi tugas, khususnya dalam melakukan presentasi di depan kelas.

\section{Aktivitas siswa}

Berdasarkan observasi yang telah dilakukan pada siklus II, terlihat bahwa 95, 45\% dari jumlah siswa telah melakukan aktivitas visual masuk kategori baik sekali, 90, 14\% dari jumlah siswa telah 
melakukan aktivitas lisan masuk kategori baik sekali, $100 \%$ dari jumlah siswa telah melakukan aktivitas mendengarkan masuk dalam kategori baik sekali, $100 \%$ dari jumlah siswa telah melakukan aktivitas menulis masuk dalam kategori baik sekali, dan 90, 9\% dari jumlah siswa telah melakukan aktivitas emosional masuk kategori baik sekali. Secara lebih jelas gambaran mengenai atkifitas belajar siswa pada Siklus II dapat dilihat dari tabel dan diagram batang di bawah ini.

Tabel 8.

Persentase Aktivitas Siswa Pada Siklus II

\begin{tabular}{clcc}
\hline No & Aktifitas yang diamati & Prosentase & Kategori \\
\hline 1 & Aktifitas Visual & $95.45 \%$ & Baik sekali \\
2 & Aktifitas Lisan & $90.14 \%$ & Baik sekali \\
3 & Aktifitas Mendengarkan & $100 \%$ & Baik sekali \\
4 & Aktifitas Menulis & $100 \%$ & Baik sekali \\
5 & Aktifitas Emosional & $90.9 \%$ & Baik sekali \\
\hline
\end{tabular}

\section{Hasil Belajar Siswa}

Nilai ketuntasan pada mata pelajaran sejarah adalah 75. Jumlah siswa kelas X IPA 7 SMA N 1 Surakarta sebanyak 33 siswa. Diketahui bahwa nilai ketuntasan siswa pada Siklus I sebanyak 5 siswa atau sebesar $15,15 \%$ yang tidak tuntas, dan sebanyak 28 siswa atau sebesar $84.84 \%$ dinyatakan tuntas dalam pembelajaran sejarah materi Kerajaan Hindu-Budha. Pada Siklus II didapatkan hasil bahwa siswa yang mencapai ketuntasan belajar Sejarah materi Kerajaan Hindu-Budha sebanyak 31 siswa atau 93,93\%. Dengan demikian dapat disimpulkan bahwa pada Siklus II pembelajaran Sejarah materi Kerajaan Hindu Budha menggunakan Kartu Kwartet Pintar Sejarah telah mengalami peningkatan, yaitu dari 28 siswa atau $84.84 \%$ menjadi 31 siswa atau 93,93\%. Hasil belajar siswa pada siklus II dapat dilihat dari tabel di bawah ini.

Tabel. 9

Perbandingan Nilai Siswa Tiap Siklus

\begin{tabular}{lccc}
\hline \multicolumn{1}{c}{ Uraian } & Kondisi Awal & Siklus I & Siklus II \\
\hline Nilai Terendah & 50 & 60 & 75 \\
Nilai Tertinggi & 100 & 100 & 100 \\
Nilai Rerata & 74,84 & 81,66 & 83,78 \\
Rentang Nilai & 50 & 40 & 25 \\
\hline
\end{tabular}

Siswa yang mencapai ketuntasan belajar, yaitu yang mencapai nilai 75 atau lebih pada siklus II ini sebanyak 33 siswa atau 100\%, sedangkan yang tidak mencapai ketuntasan belajar sebanyak 0 siswa atau 0,00\%. Dengan demikian dapat disimpulkan bahwa hasil belajar siswa dalam pembelajaran Sejarah materi Kerajaan Hindu Budha menggunakan Kartu Kwartet Pintar Sejarah pada Siklus II telah mengalami peningkatan, yaitu dari 28 siswa atau atau 84, 84\% meningkat menjadi 33 siswa atau $100 \%$. Secara lebih jelas dapat dilihat dari tabel perbandingan antara siklus I dan siklus II di bawah ini.

Tabel. 10

Perbandingan Ketuntasan Hasil Belajar Siswa Tiap Siklus

\begin{tabular}{ccccc}
\hline \multirow{2}{*}{ Uraian } & \multicolumn{2}{c}{ Siklus I } & \multicolumn{2}{c}{ Siklus II } \\
\cline { 2 - 5 } & Frekuensi & Presentase & Frekuensi & Presentase \\
\hline$\leq 75$ & 5 & 15.15 & 0 & 0 \\
$>75$ & 28 & 84.84 & 33 & 100 \\
Jumlah & 33 & 100 & 100 & 100 \\
\hline
\end{tabular}


Berdasarkan hasil pengamatan yang dilakukan pada pelaksanaan pembelajaran Sejarah materi Kerajaan Hindu-Budha menggunakan Kartu Kwartet Pintar Sejarah pada siklus II, aktivitas belajar Sejarah materi Kerajaan Hindu-Budha pada siklus II mengalami peningkatan. Demikian juga dengan hasil belajar siswa yang mengalami peningkatan yang dapat dilihat dari meningkatnya jumlah siswa yang mencapai ketuntasan belajar dan rata-rata kelas.

\section{Pembahasan}

Aktivitas yang diamati selama proses pembelajaran dibagi menjadi 5 aspek, mulai dari kegiatan visual, lisan, mendengarkan, menulis, dan aktivitas emosional siswa. Hasil penelitian menunjukkan bahwa pada kondisi awal terlihat bahwa aktivitas lisan memiliki nilai atau presentase paling rendah dibanding aktivitas yang lain, yaitu sebesar 18, 93\% dari jumlah siswa.

Kegiatan pembelajaran yang dilakukan masih berpusat pada guru, sehingga kurang memberikan dorongan pada siswa untuk aktif terutama secara lisan. Siswa juga tampak kurang antusias dalam mengikuti proses pembelajaran. Oleh karena itu diperlukan tindakan untuk merangsang aktivitas siswa. Dalam hal ini pembelajaran Sejarah materi Kerajaan HinduBudha menggunakan Kartu Kwartet Pintar Sejarah untuk meningkatkan aktivitas belajar siswa kelas X IPA 7 SMA N 1 Surakarta.

Pada siklus I, aktivitas lisan terjadi peningkatan yaitu dari 18, 93 menjadi 46, 96\% dari jumlah siswa. Hal ini membuktikan bahwa tindakan pada siklus I dapat meningkatkan aktivitas belajar siswa pada mata pelajaran Sejarah. Peningkatan aktivitas belajar siswa pada siklus I disebabkan model pembelajaran menggunakan Kartu Kwartet Pintar Sejarah, karena siswa dikondisikan untuk melakukan presentasi di depan kelas, mengajukan pertanyaan serta menjawab pertanyaan. Hal ini memungkinkan untuk meningkatkan aktivitas lisan siswa.

Peningkatan aktivitas belajar juga terjadi pada aktivitas visual, aktivitas mendengarkan, aktivitas menulis dan aktivitas emosional. Pada pra siklus aktivitas sebesar 37, 87\% dan meningkat menjadi $72,72 \%$. Aktivitas mendengarkan sebesar $63,63 \%$ menjadi 93 , $93 \%$, aktivitas menulis sebesar $63,63 \%$ menjadi 96, 96\%, dan aktivitas emosional sebesar 25, $75 \%$ meningkat menjadi $53,02 \%$.
Aktivitas siswa yang tergolong masih rendah pada siklus I adalah aktivitas lisan dan aktifitas emosional walaupun dalm kategori cukup. Hal ini disebabkan karena pada saat proses presentasi hanya dilakukan oleh perwakilan kelompok sehingga anggota kelompok yang lain kurang berperan aktif. Selain itu, hanya beberapa siswa saja yang berani mengajukan pertanyaan, atau mengungkapkan ide dan gagasannya atau memberikan tanggapan. Kendala yang muncul pada siklus I diperbaiki pada siklus II. Pada siklus II guru meminta seluruh siswa untuk aktif di dalam kelompoknya masing-masing, seperti dalam memberikan ide atau gagasan, berani mengajukan pertanyaan, menjawab pertanyaan dan presentasi di depan kelas sehingga seluruh anggota kelompok dapat berperan aktif.

Setelah dilakukan perbaikan tindakan pada siklus II, aktivitas belajar Sejarah materi Kerajaan Hindu-Budha pada siklus II sudah mencapai kriteria keberhasilan tindakan. Berdasarkan hasil pengamatan yang telah dilakukan, juga terlihat bahwa beberapa aspek aktivitas siswa pada pra tindakan meningkat pada siklus I dan meningkat lagi pada siklus II.

Berdasarkan hasil pengamatan yang telah dilakukan, beberapa aspek aktivitas siswa pada pra tindakan meningkat pada siklus I dan meningkat lagi pada siklus II. Aktivitas visual pada pra tindakan $37,87 \%$ meningkat menjadi $72.72 \%$ pada siklus I, dan meningkat lagi menjadi 95, 45\% pada siklus II. Aktivitas lisan pada pra tindakan $18,93 \%$ meningkat menjadi 46, $96 \%$ pada siklus I, dan meningkat lagi menjadi 90, 14\% pada siklus II. Aktivitas mendengarkan pada pra tindakan 63, 63\% meningkat menjadi $93.93 \%$ pada siklus I, dan meningkat lagi menjadi $100 \%$ pada siklus II. Aktivitas menulis pada pra tindakan 63, 63\% meningkat menjadi $96,96 \%$ pada siklus I, dan meningkat lagi menjadi $100 \%$ pada siklus II. Aktivitas emosional pada pra tindakan 25, 75\% meningkat menjadi $53,02 \%$ pada siklus I, dan 90, 9\% pada siklus II. Berikut ini tabel persentase setiap aspek aktivitas siswa pada pra tindakan, siklus I, dan Siklus II. Mengenai peningkatan aktivitas belajar siswa pada setiap siklus dapat dilihat pada tabel dan diagram balok di bawah ini. 
Tabel 11.

Persentase Perbandingan Aktivitas Siswa tiap Siklus

\begin{tabular}{l|c|c|c|c|c|c}
\multirow{2}{*}{ Aktifitas yang diamati } & \multicolumn{2}{|c|}{ Pra Siklus } & \multicolumn{2}{c|}{ Siklus I } & \multicolumn{2}{c}{ Siklus II } \\
\cline { 2 - 7 } & $\%$ & Kategori & $\%$ & Kategori & $\%$ & Kategori \\
\hline Aktifitas Visual & $37.87 \%$ & Kurang & $68.17 \%$ & Cukup & $95.45 \%$ & Baik sekali \\
\hline Aktifitas Lisan & $18.93 \%$ & Kurang sekali & $26.41 \%$ & Kurang & $90.90 \%$ & Baik sekali \\
\hline Aktifitas Mendengarkan & $63.63 \%$ & Cukup & $85.85 \%$ & Baik sekali & $100 \%$ & Baik sekali \\
\hline Aktifitas Menulis & $63.63 \%$ & Cukup & $96.96 \%$ & Baik sekali & $100 \%$ & Baik sekali \\
\hline Aktifitas Emosional & $25.75 \%$ & Kurang & $45 \%$ & Cukup & $90.9 \%$ & Baik sekali
\end{tabular}

Demikian juga dengan hasil belajar siswa, selalu terjadi peningkatan dalam setiap siklus. Hal ini dapat dilihat dari ketuntasan belajar siswa dan rata-rata kelas yang dicapai oleh siswa. Rata-rata kelas mengalami peningkatan pada setiap siklus. Pada pra siklus rata-rata kelas sebesar 74, 84 meningkat menjadi 81, 66 pada siklus I dan meningkat lagi menjadi 83, 78 pada siklus II. Pada pra siklus siswa yang telah mencapai ketuntasan belajar sebanyak 20 siswa atau 60, 60\% meningkat menjadi 28 siswa atau $84,84 \%$ pada siklus I dan meningkat lagi menjadi 33 siswa atau $100 \%$ pada siklus II. Hal tersebut dapat dilihat berdasarkan tabel di perbandingan ketuntasan belajar tiap siklus di bawah ini.

Tabel. 12

Perbandingan Ketuntasan Hasil Belajar Siswa Tiap Siklus

\begin{tabular}{c|cc|cc|cc}
\hline \multirow{2}{*}{ Uraian } & \multicolumn{2}{|c|}{ Kondisi awal } & \multicolumn{2}{c|}{ Siklus I } & \multicolumn{2}{c}{ Siklus II } \\
\cline { 2 - 7 } & Frekuensi & Presentase & Frekuensi & Presentase & Frekuensi & Presentase \\
\hline$\leq 75$ & 13 & 39.40 & 5 & 15.15 & 0 & 0 \\
$>75$ & 20 & 60.60 & 28 & 84.84 & 33 & 100 \\
Jumlah & 33 & 100 & 33 & 100 & 100 & 100 \\
\hline
\end{tabular}

\section{PENUTUP}

Berdasarkan pelaksanaan tindakan yang sudah dilakukan di atas, maka penelitian ini dapat disimpulkan sebagai berikut:

1. Pembelajaran dengan menggunakan Kartu Kwartet Pintar Sejarah dapat meningkatkan aktifitas belajar siswa pada mata pelajaran sejarah materi Kerajaan Hindu Budha. Hal ini terbukti dengan meningkatnya aktifitas siswa pada tiap siklus, yaitu pada pra siklus aktifitas visual $37.87 \%$, aktifitas lisan 18, 93\%, aktifitas mendengarkan 63, 63\%, aktifitas menulis $63,63 \%$, aktifitas emosional $45 \%$. pada siklus I aktifitas visual $68,17 \%$, aktifitas lisan 26, 41\%, aktifitas mendengarkan 85, 85, aktifitas menulis 96, 96\%, aktifitas emosional $45 \%$. Pada siklus II aktifitas visual 95, 45\%, aktifitas lisan 90, 90\%, aktifitas mendengarkan $100 \%$, aktifitas menulis $100 \%$, aktifitas emosional 90, 9\%

2. Pembelajaran dengan menggunakan Kartu Kwartet Pintar Sejarah dapat meningkatkan hasil belajar siswa pada mata pelajaran sejarah materi Kerajaan Hindu Budha. Hal ini terbukti dengan meningkatnya aktifitas siswa pada tiap siklus. Pada pra siklus kurang dari 75 adalah $39,40 \%$, siklus I sebesar $15,15 \%$, siklus II sebesar 0\%. Adapun di atas 75 adalah $60,60 \%$, siklus I sebesar $84,84 \%$, dan siklus II sebesar $100 \%$.

3. Pembelajaran dengan menggunakan Kartu Kwartet Pintar Sejarah dapat meningkatkan aktifitas dan hasil belajar siswa pada mata pelajaran sejarah materi Kerajaan Hindu Budha. Hal ini terbukti dengan meningkatnya aktifitas siswa dan hasil belajar siswa pada tiap siklus. pada aktifitas siswa seluruh aspek telah mencapai kategori baik sekali sedangkan untuk keberhasilan belajar seluruh siswa telah emncapai ketuntasan belajar.

Berdasarkan hasil penelitian dan pembahasan, dapat disimpulkan bahwa penerapan Kartu Kwartet Pintar Sejarah dapat meningkatkan aktivitas belajar siswa dan hasil belajar siswa pada pembelajaran sejarah materi Kerajaan Hindu-Budha kelas X IPA 7 SMA N 1 Surakarta. 


\section{Implikasi}

Berdasarkan hasil penelitian dan pembahasan dalam penerapan model pembelajaran menggunakan Kartu Kwartet Pintar Sejarah dapat dikemukakan implikasi sebagai berikut.

1. Strategi pembelajaran merupakan hal yang sangat penting dilakukan guru dalam menyampaikan materi kepada siswa. Strategi pembelajaran menggunakan Kartu Kwartet Pintar Sejarah yang sudah dilakukan menunjukkan hasil adanya peningkatan pada aktifitas belajar dan hasil belajar siswa.

2. Hasil penelitian ini juga berimplikasi pada perubahan paradigma pembelajaran berpusat pada guru menjadi berpusat pada siswa. melalui pembelajarn menggunakan Kartu Kwartet Pintar Sejarah terbukti bahwa siswa lebih aktif, baik dari aspek visual, lisan, mendengarkan, menulis, dan emosional. Selain penggunaan Kartu Kwartet Pintar Sejarah juga mampu meningkatkan hasil belajar siswa. Hal tersebut tampak pada meningkatnya rata-rata kelas dan jumlah siswa yang mencapai ketuntasan belajar.

\section{Saran}

Dari kesimpulan yang telah dipaparkan sebelumnya, dapat diajukan beberapa saran sebagai berikut.

1. Bagi sekolah

Pihak sekolah hendaknya memberikan pelatihan kepada guru tentang cara menyajikan pembelajaran inovatif seperti penggunaan Kartu Kwartet Pintar Sejarah.

2. Bagi guru

a. Sebaiknya guru menyampaikan pembelajaran menggunakan model pembelajaran yang dapat membuat siswa aktif agar potensi yang ada dalam diri siswa dapat berkembang..

b. Sebaiknya guru selalu memberi motivasi, bimbingan dan selalu menghargai setiap usaha siswa.

\section{Bagi siswa}

Sebaiknya siswa lebih rajin belajar. berani dalam menyampaikan pertanyaan, ide, dan pendapatnya.

\section{DAFTAR PUSTAKA}

Arikunto, Suharsimi. 2002. Prosedur Penelitian Suatu Pendekatan Praktik. Jakarta: Rineka Cipta.

Dananjaya. 2010. Media Pembelajaran Aktif. Bandung: Nuansa.

Mulyasa, E. 2007. Standar Kompetensi dan Sertifikasi Guru. Bandung: Remaja Rosdakarya.

Nana Sudjana. 2005. Penilaian Hasil Proses Belajar Mengaja. Bandung: Rasdakarya.

Sardiman, A.M. 2004. Interaksi dan Motivasi Belajar Mengajar. Jakarta: Raja Grafindo Persada.

Tim Penyusun Kamus Pusat dan Pengembangan Bahasa. 2008. Kamus Besar Bahasa Indonesia. Jakarta: PT. Gramedia Pustaka Umum. 